\title{
WS068 コウホート研究への招待－調査デザインと分析法ー
}

\author{
企画者：横山 詔一（国立国語研究所） \\ 企画者：前田 忠彦（統計数理研究所） \\ 企画者: 中村隆（統計数理研究所） \\ 司会者：前田 忠彦（統計数理研究所） \\ 話題提供者 : 前田 忠彦 (統計数理研究所) \\ 話題提供者：中村隆\#（統計数理研究所） \\ 話題提供者：横山 詔一 (国立国語研究所) \\ 指定討論者 : 河合 優年 (武庫川女子大学)
}

認知能力等に関する生涯変化の軌跡をとらえる大規模な調查研究が諸科学の注目を浴びている。その 方法の代表格は「コウホート (Cohort) 研究」であろう。コウホート研究のデザインにはいくつかの バリエーションがある。ここでは, 統計数理研究所による反復横断調査「日本人の国民性調查」のほか, 国立国語研究所と統数研が60年間以上にわたって定点観測してきた社会言語学的調査などを取り上げ, その方法論と心理学的意義を考える。

国語研と統数研による社会言語学的調查は, 横断研究と縦断研究を組み合わせた「コウホート系列法」 という調査デザインを1950年から用いている。同様の方法は，世界を見わたしても知能の生涯発達・変 化に関する米国のシアトル調查ぐらいしか見当たらないが，国語研と統数研の社会言語学的調查はそれ よりも長期間にわたっている。それらのデー夕から, 言語運用能力に対する加齢効果, 世代効果, 時代 効果の大きさを解析できる。 